\title{
Total mercury in hair of polar bears (Ursus maritimus) from Greenland and Svalbard
}

\author{
ERIK W. BORN, ARISTEO RENZONI and RUNE DIETZ
}

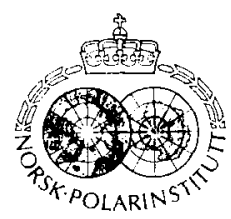

Born, E. W., Renzoni. A. \& Dietz, R. 1991: Total mercury in hair of polar bears (Ursus maritimus) from Greenland and Svalbard. Polar Research 9(2), 113-120.

Concentrations $(\mathrm{ppm}=\mu \mathrm{g} / \mathrm{g} \mathrm{dry}$ wcight $)$ of total mercury $(\mathrm{Hg})$ were determined in hair of polar bears (Ursus maritimus) from northwestern Greenland $(\mathrm{N}=22$ : pcriod of sampling: 1978-1989), castern Grecnland ( $N=44: 1984-1989)$ and Svalbard $(\mathrm{N}=31 ; 1980)$. For subadults (2-6 years of life), adults ( $7-10$ ycars). and old bears $(>10$ ycars). concentrations of total $\mathrm{Hg}$ in hair were not found to be dependent on age or sex. A decreasing trend in $\mathrm{Hg}$ concentrations was found from west to east. The mean concentrations of total $\mathrm{Hg}$ in hair (cubs of the year and yearlings excluded) were: northwcstern Grecnland, $\bar{x}=8.38 \mathrm{ppm}$ (min.-max.: $4.71-14.19 \mathrm{ppm}, \mathrm{N}=21)$; eastern Greenland: $\overline{\mathrm{x}}=4.58 \mathrm{ppm}(\min .-\max .: 2.50-8.83 \mathrm{ppm} . \mathrm{N}=$ 41 ): and Svalbard, $\bar{x}=1.98 \mathrm{ppm}$ ( $\min \cdot-\max .: 1,02-4.55 \mathrm{ppm}, \mathrm{N}=29$ ). Concentrations found in northwestern Greenland were similar to those reported by others from the hair of polar bcars sampled within management zone $\mathrm{F}$ of the eastern Canadian High Arctic. Concentrations of total $\mathrm{Hg}$ in polar bear hair from eastern Greenland were similar to concentrations found by others in contemporary (1988) material collected during spring in western Svalbard. However, the mean concentration of total $\mathrm{Hg}$ in the 1980 Svalbard material, which was collected during July-September, was significantly lower than concentrations found in samples taken during late winter and spring in eastern Greenland and at Svalbard, respectively. Presumably the relatively low concentrations found in the 1980 Svalbard sample arc attributable to the period of moult and hence a larger proportion of newly grown hair in the individual samples. In a subsample consisting of internal tissues from 19 polar bears from eastern Greenland (1984-1987), concentrations of total $\mathrm{Hg}$ in hair correlated positively with concentrations of total $\mathrm{Hg}$ (wet weight) in muscle $(\mathrm{N}=6$ ), liver $(\mathrm{N}=19)$ and kidney $(\mathrm{N}=19)$ tissue. For liver and kidney tissue these relationships were statistically significant.

Erik W. Born. Greenland Fisheries Research Institute, Tagensvej 135, DK-2200 Copenhagen N, Denmark; Aristeo Renzoni, Dipartimento Biologia Ambientale, Università di Siena, Via delle Cerchia 3, 53100 Siena, Italy; Rune Dietz, Greenland Environmental Research Institute. Tagensvej 135, DK-2200 Copenhagen N. Denmark

\section{Introduction}

Hair samples of mammals are considered to be good indicators of the body burden of mercury (Jóhannesson et al. 1981; Hansen 1981; Renzoni 1989). Concentrations in hair reflect blood mercury or body burden of mercury during time of hair growth (Sexton et al. 1978; Kershaw et al. 1980). Being a top predator which feeds almost exclusively on seals and in particular ringed seals (Phoca hispida; e.g. Stirling \& Archibald 1977; Lønø 1970), the polar bear can be considered a good indicator of the degree of bioaccumulation of persistent contaminants in its ecosystem. Based on analyses of 128 recent (1977-1980) and 18 museum samples (1910-1927), Eaton \& Farant (1982) presented concentrations of total mercury $(\mathrm{Hg})$ in polar bear hair from eight different localities in the Canadian High Arctic. Liver samples from 67 polar bears from 1982 were analysed for mercury and 21 other elements by Norstrom et al. (1986). Renzoni \& Norstrom (1990) gave concentrations of total $\mathrm{Hg}$ in hair sampled between 1976 and 1988 from a total of 141 polar bears in various localities in the Canadian Arctic, the USSR, and at Svalbard (Norway). Concentrations of total and organic $\mathrm{Hg}$ in muscle, liver and kidney in polar bears from central-eastern Greenland were presented in Dietz (1987), Dietz et al. (1990) and Dietz \& Agger (in press). Here we present the results of analyses of total $\mathrm{Hg}$ in hair from 66 polar bears from three localities in Greenland with a note on the relationship between concentrations of total $\mathrm{Hg}$ found in hair and in muscle, liver and kidney tissue. For comparative reasons analyses of total $\mathrm{Hg}$ in 31 polar bear hair samples obtained at Svalbard during July-September 1980 are included. 


\section{Material and methods}

A total of 66 hair samples ( $28 \mathrm{~F}, 37 \mathrm{M}, 1$ undet.) from Greenland and 31 samples (15 F, 16 M) from Svalbard have been analysed for contents of total $\mathrm{Hg}$. The majority of the Greenland samples were collected by hunters from their subsistence catch of polar bears. Between January 1984 and August 1989 a total of 40 samples (year/sample size: $1984 / 11 ; 1985 / 2 ; 1986 / 1 ; 1987 / 4 ; 1988 / 8$; $1989 / 13$; unknown/1) were obtained from the Scoresby Sound region of eastern Greenland (Fig. 1). Four samples ( $2 \mathrm{~F}, 2 \mathrm{M})$ were obtained in 1989 from the Ammassalik area in southeastern Green-

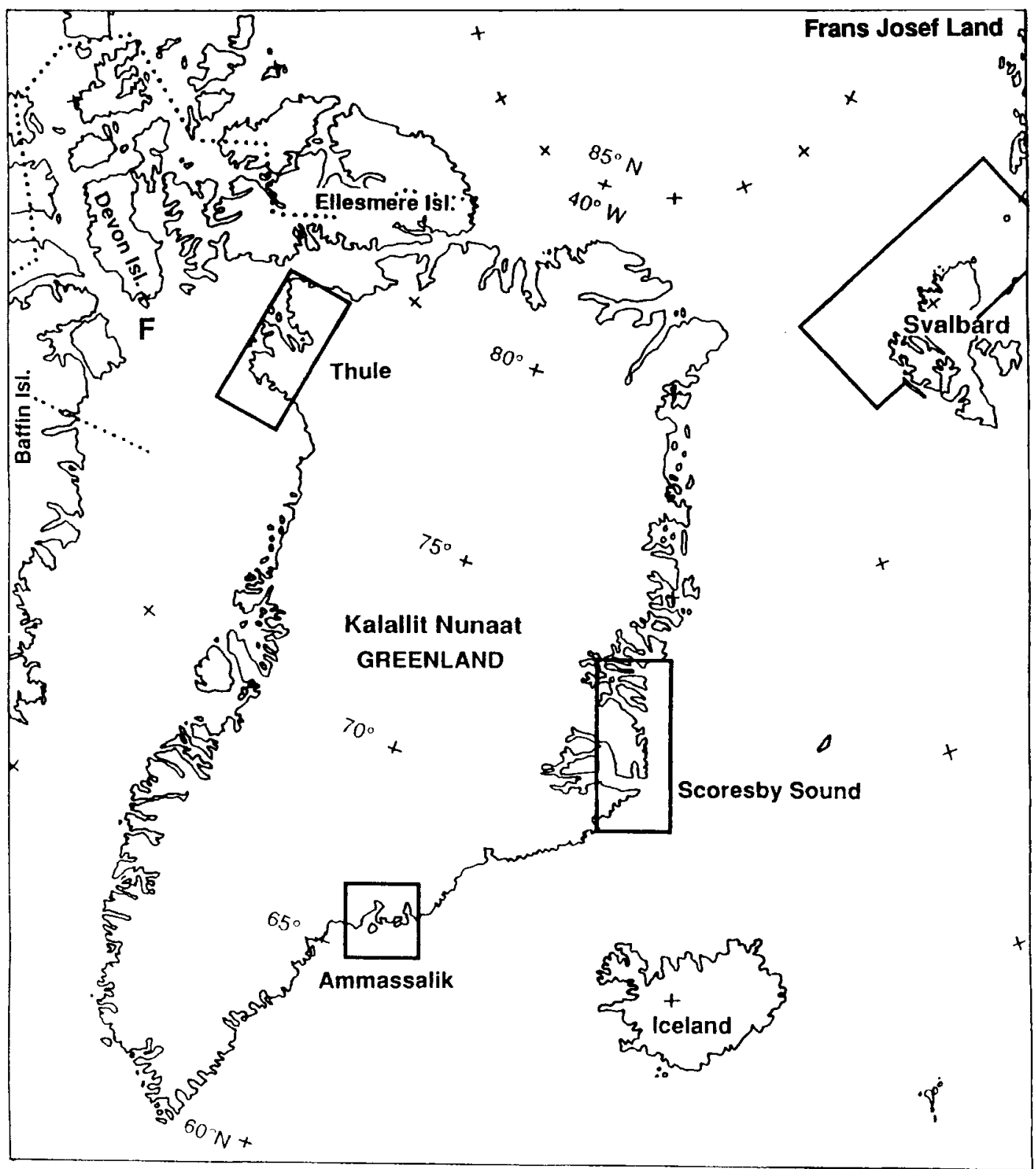

Fig. 1. Areas in which polar bear hair samples andysed in this study were obtained. The borders of the Canadian polar bear management zone $F$ atre shown with a dotted line $(\cdots \cdots)$. 
land; a total of 22 samples $(8 \mathrm{~F}, 14 \mathrm{M})$ were collected in the Avanersuaq (Thule) area in northwestern Greenland. Four of these samples were collected by scientists in May 1978; the remainder were collected by local hunters in $1988(\mathrm{~N}=7)$ and $1989(\mathrm{~N}=11)$. A total of 31 hair samples were collected by scientists during a Swedish icebreaker expedition (YMER) operating in the Svalbard area in 1980 . The vast majority of the Greenland samples were from late winter and spring (January-May) while the Svalbard-material was collected during "summer" (July-September; Fig. 2). For 19 of the polar bears from the Scoresby Sound material (1984-1987), additional information was available on total mercury content in muscle $(\mathrm{N}=6)$, liver $(\mathrm{N}=19)$ and kidney $(\mathrm{N}=$ 19) tissue.

The hair samples were kept frozen in polyethylene plastic bags until analysis (with the exception of the 1978 Thule samples, which were stored dry in paper bags). The samples were carefully washed in acetone, rinsed and dried before being analysed for mercury residues at the laboratory of Dipartimento Biologia Ambientale (Siena) by atomic absorption spectrophotometry as described in Renzoni et al. (1986). Samples of internal tissues were kept frozen and stored in polyethylene plastic bags before being analysed at the laboratory of Greenland Environmental Research Institute by a method described in Dietz et al. (1990).

To detect whether concentrations of total $\mathrm{Hg}$ in hair correlated with age, the polar bears were grouped into five age classes: cub of the year $=$ COY, yearling, subadult, adult, and old. The age classes were based either on age obtained from reading of the annual layering in tooth cementum or on field age class estimates and body length. For a sub-sample from Scoresby Sound $(\mathrm{N}=19$; 1984-1987), individual ages were determined from the counting of the annual layering in the cementum of the lower premolars as described in Stirling et al. (1977). For the 1978 Thule-sample and the 1980 Svalbard-sample, ages were esti-
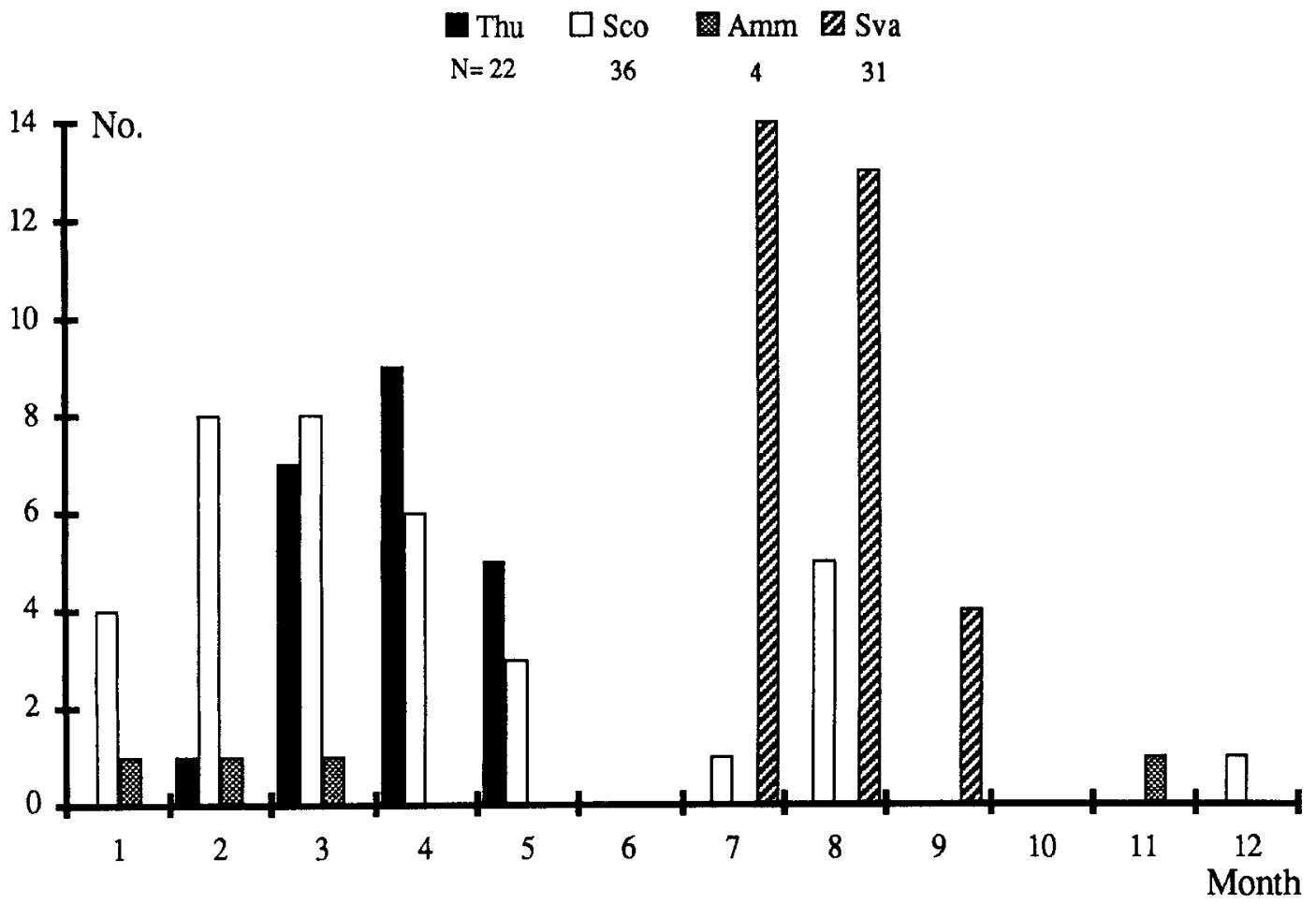

Fig. 2. Seasonal distribution of polar bear sampling from three different regions in Greenland $($ Thu $=$ Thule: $S c o=S c o r e s b y$ Sound; Amm = Ammassalik) and Svalbard (Sva). Four samples from Scoresby Sound presented in Table 2 had no information on the date of sampling. 
Table 1. Polar bear age classes with zoological body lengths used in analyses of relationship between tolal $\mathrm{Hg}$ in hair and age

\begin{tabular}{|c|c|c|c|c|c|}
\hline Age tlass & & $\begin{array}{l}\text { Mcan length } \\
(\mathrm{cm})\end{array}$ & $\mathrm{SD}$ & $\begin{array}{l}\text { Min.- } \\
\text { Max. }\end{array}$ & $x$ \\
\hline \multirow[t]{2}{*}{$\operatorname{cor}$} & 11 & 1617 & $\ldots$ & - & 1 \\
\hline & $\mathrm{F}$ & - & - & - & 一 \\
\hline \multirow[t]{2}{*}{ rearlings } & 11 & 177 & $\ldots$ & - & 1 \\
\hline & $F$ & $14 ;$ & $1: 2$ & $126-157$ & + \\
\hline Subadults & $\$$ & $2(x)$ & 1.9 & $173-251$ & $1+$ \\
\hline $12-6 ! r)$ & $F$ & $|M|$ & 18.2 & ביבב-160 & 10 \\
\hline Adulin (?-10,y) & $M$ & 224 & 14.5 & $185-259$ & 15 \\
\hline Old 1.11 yr 1 & 11 & $2+2$ & 18.1 & $215-273$ & 17 \\
\hline $\begin{array}{l}\text { Aduts and oll } \\
\text { in and older }\end{array}$ & $\mathrm{F}$ & 211 & 16.6 & $176-2211$ & 211 \\
\hline
\end{tabular}

mated in the field by scientists. The majority of the Gireenland material was categorized into age classes according to estimates of age given by the hunters in the field together with zoological body length measured from tip of snout to tip of tail along the back when the bear was positioned on its belly. Length data for these age classes are presented in Table 1 where adult and old females are pooled hecause there was no difference in average body length of these age classes $(\mathrm{F}=$ $0.595 . \mathrm{df}=1 / 1 \mathrm{~h} . \mathrm{P}>0.05)$.

Concentrations of total $\mathrm{Hg}$ are given as $\mathrm{ppm}$ ( $\mu \mathrm{g} / \mathrm{g}, \mathrm{d} . \mathrm{w}$.$) in hair and as ppm (\mu \mathrm{g} / \mathrm{g}, \mathrm{w} . \mathrm{w}$.$) in$ other tissues

The distrihutions of $\mathrm{Hg}$ in hair in the differ- ent areas did not differ significantly from normality (Kolmogorov-Smirnov one-sample tests: $P>0.05)$ but had significantly different variances (Bartlett's test. $X^{2}=19.567 . P<0.01$ ). All data were in-transformed and ANOVA analyses were performed using the factors: area, sex, age, and the respective interactions of these. Statistics were made using Statview II and SuperANOVA for a Macintosh microcomputer.

\section{Results}

$\mathrm{Hg}$ in hair

Concentrations of total $\mathrm{Hg}$ found in polar bear hair in the four different areas are presented in Table 2. Values for the two youngest age groups are given separately because young bears (i.e. cubs of the year = COYS and yearlings) are assumed to be dependent on milk until they are well into their second year of life (Lønø 1970). Most cubs become independent when they are a little over 24 months old (Larsen 1986). In none of the samples were concentrations of total $\mathrm{Hg}$ in hair related to either age (age classes: subadults, adults, olds) or to sex (two factor ANOVAs: $P>0.05)$. Therefore, data from these two categories were pooled for further analyses. As concentrations of total $\mathrm{Hg}$ in polar bear from Ammassalik in southeastern Greenland did not differ significantly from concentrations found in hair from the Scoresby Sound region $(F=0.446$. $\mathrm{P}<0.05$, $\mathrm{df}=1 / 39)$. the samples from these

Tiable 2. Concentrations (ug g d.h.) of tolal mercury in hair of polar bears from Greenland (1978-1989) and Svalbard (1980). The average and crror ranges ars calculated from the antilogarithms of the mean and the standard deviation of the ln-transformed datia.

\begin{tabular}{|c|c|c|c|c|c|c|}
\hline \multirow[b]{2}{*}{ Locition } & \multirow[b]{2}{*}{ Year } & \multirow[b]{2}{*}{ Age groups } & \multicolumn{4}{|c|}{ Total Hg (ppm) } \\
\hline & & & $\begin{array}{l}\text { Geo. } \\
\text { Meadt }\end{array}$ & $\begin{array}{c}\text { Standard error } \\
\text { range } \\
\left.\mathrm{c}^{2} \text { (i) }-\mathrm{e}^{3}-\mathrm{S}\right\}\end{array}$ & $\operatorname{Min}-\operatorname{Max}$ & $N$ \\
\hline \multirow[t]{2}{*}{ Thule } & $1978-1989$ & Yearling & 9.51 & & - & 1 \\
\hline & & 2 years and older & 8.38 & $6.38-11.01$ & $4.71-14.19$ & 21 \\
\hline \multirow[t]{2}{*}{ Scorcthy Sound } & $19 x+19 x y$ & Yearlings & 1.81 & $1.63-2.011$ & $1.6 .5-2.03$ & 3 \\
\hline & & 2 varse and older & +62 & 3.396 .17 & $2.50-8.83$ & 37 \\
\hline Ammassalik & $19 \pi$ & 2 vears and older & 4.21 & $3.68-4.82$ & $3.41-6.02$ & 4 \\
\hline \multirow[t]{3}{*}{ Srathard } & 19801 & Cuto of the year & 0.3 .4 & & - & l \\
\hline & & Ycarling & 1.174 & & - & 1 \\
\hline & & 2 yoars and older & 1.98 & $1.33-2.96$ & $1.02-4.55$ & 29 \\
\hline
\end{tabular}


areas were pooled. The geometric mean concentrations of $\mathrm{Hg}$ differed significantly between the three main areas $(\mathrm{F}=122.09, \mathrm{df}=2 / 88$, $\mathrm{P}<0.01)$. The northwestern Greenland $\mathrm{Hg}$-concentration was 1.8 times and 4.3 times higher than mean concentration in eastern Greenland and at Svalbard, respectively (Table 2).

Concentrations found in hair from eastern Greenland were significantly higher than concentrations found in the sample taken at Svalbard in 1980, but similar to concentrations reported by Renzoni \& Norstrom (1990) for a sample obtained from Svalbard during the spring of 1987 and 1988 (Tukey's test; $\mathrm{P}<0.01$ ).

In the East Greenland sample the concentrations of total $\mathrm{Hg}$ in hair collected during July and August $(\bar{x}=5.23 \mathrm{ppm}$, rel. $\mathrm{SD}=1.26$, min.max.: $3.54-6.62 \mathrm{ppm}, 5 \mathrm{M}$ and $1 \mathrm{~F}$ ) did not differ significantly from concentrations in hair at other times of the year $(F=0.066 ; \mathrm{df}=3 / 33 ; \mathrm{P}<0.05)$. Insufficient seasonal representation did not allow similar analyses to be performed for the other samples.

\section{Hg in muscle, kidney and liver}

The relationships of concentrations of total $\mathrm{Hg}$ in hair to concentrations of total $\mathrm{Hg}$ in muscle, kidney and liver tissue from 19 polar bears sampled in the Scoresby Sound region (eastern Greenland) between 1984 and 1987 in the period December-April are shown in Fig. 3. Concentrations of mercury in hair were found to be positively correlated with concentrations in tissue from kidney $(r=0.480, N=19, P<0.05)$, liver $(\mathrm{r}=0.685, \mathrm{~N}=19, \mathrm{P}<0.05)$, and muscle $(\mathrm{r}=$ $0.574, \mathrm{~N}=6$, n.s.). The slopes of the regression lines were significantly different from 0 at the same probability level for kidney and liver tissue, whereas no significance was detected for muscle tissue, probably due to the low number of samples.

\section{Discussion}

Concentrations of total $\mathrm{Hg}$ in polar bear hair were highest in northwestern Greenland. However, the concentrations were in the same order of magnitude as those reported by Eaton \& Farant (1982) and Renzoni \& Norstrom (1990) from the eastern Canadian High Arctic (i.e. within the Canadian management zone F; Fig. 1). Recaptures in north-
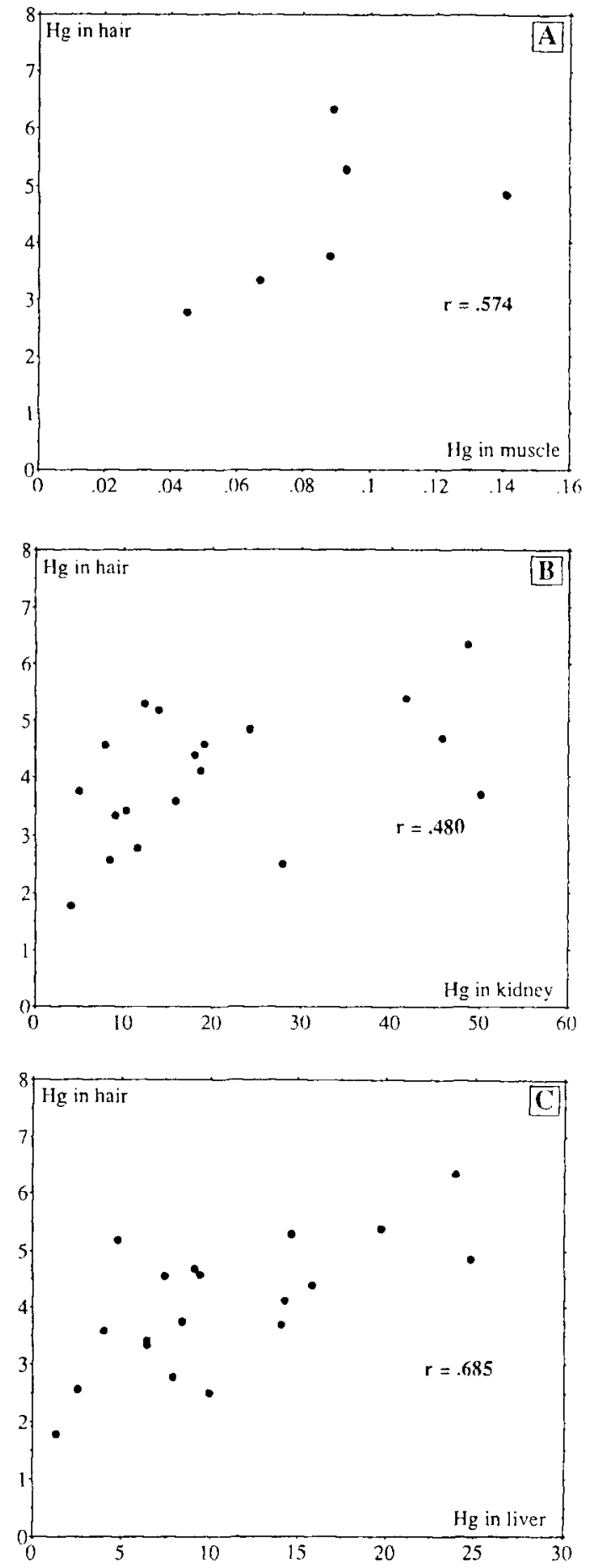

Fig. 3. Total mercury in hair $(\mu \mathrm{g} / \mathrm{g}$ d.w.) versus total mercury $(\mu \mathrm{g} / \mathrm{g}$ w.w. $)$ in muscle $\mathrm{A}(\mathrm{N}=6)$. kidney $\mathrm{B}(\mathrm{N}=19)$ and liver tissue $\mathrm{C}(\mathrm{N}=19)$ in polar bears from Scoresby Sound (1984 $1987)$ in eastern Greenland. Note the differences in seale of the $\mathrm{X}$-axis. 
western Greenland of polar bears which were marked in zone F (Rosing-Asvid \& Born 1990) indicate that polar bears move freely between these areas.

Concentrations of total $\mathrm{Hg}$ in hair from polar bears from eastern Greenland were similar to values reported by Renzoni \& Norstrom (1990) for a sample taken during spring in western Svalbard. Satellite tracking (Larsen et al. 1983) and movements of marked bears (Larsen 1986) indicate that exchange occurs between polar bears in eastern Greenland and in the Svalbard - Frans Josef Land region. However, to what extent local groups of bears exist within this range still remains undetermined (Born \& Rosing-Asvid 1989).

Eaton \& Farant (1982) and Renzoni \& Norstrom (1990) suggested that geographical variation in concentrations of total $\mathrm{Hg}$ in the hair of polar bears in the Canadian High Arctic to some extent reflects different ratios of the bottom-feeding bearded seals (Erignathus barbatus) to the more pelagic ringed seals in the diet of the bears in the various areas. The very limited and highly heterogeneous information available on the feeding of polar bears in Greenland (Pedersen 1945: Born upubl. data) and at Svalbard (Lønø 1970) does not allow for an evaluation of geographical variation in polar bear diet in these areas. On the other hand. Dietz \& Agger (in press) state that the only differences found in mercury levels in bearded seals and ringed seals from NW Greenland are found in liver tissue. as also found in Smith \& Armstrong (1975) in Canada, whereas no differences were found between these two species in blubber and muscle and kidney tissue.

We suggest that the differences found in our study in concentrations of total $\mathrm{Hg}$ in hair from Greenland polar bears mainly reflect variations in the overall mercury burden of the environment rather than different proportions of various prey species in their diet.

Norstrom et al. (1986) found that mercury concentrations in polar bears from the western part of the Canadian Arctic tended to be higher than in the eastern part. Likewise mercury concentrations in the northern areas at Melville Island were higher than in southern regions. Dietz \& Agger (in press), who found that concentrations of total $\mathrm{Hg}$ in the liver tissue of polar bears from eastern Greenland were lower than those reported by Norstrom et al. (1986), confirm a decreasing trend in $\mathrm{Hg}$ concentrations from west to east.
Higher concentrations of $\mathrm{Hg}$ were found in polar bear hair sampled at southwestern Svalbard in 1987 and 1988 (Renzoni \& Norstrom 1990) than in a sample from the pack ice areas around the archipelago in 1980. To our knowledge there is no information which indicates that the total mercury burden of the marine environment of the Svalbard region has increased within the last decade and we suspect that the relatively low concentrations of total $\mathrm{Hg}$ found in the 1980sample from Svalbard reflect seasonal variation related to moulting of hair. The 1980 Svalbardsamples (this study) were collected from "summer fur" while the samples analysed by Renzoni \& Norstrom (1990) were taken during March-April from "winter fur." The majority of samples from Greenland were collected between January and May from "winter fur" (Fig. 2) which presumably is also the case with samples in other studies (Eaton \& Farant 1982; Renzoni \& Norstrom 1990). Although information on the timing of the process of moulting in polar bears is somewhat contradictory (Freuchen 1935; Pedersen 1945; Uspenski 1979 citing Rutilevski 1939; Vibe 1981), it appears that generally the moult begins in late May and that the new winter coat has grown in autumn (September-October?).

Our assumption that hairs of "summer fur" have lower concentrations of total $\mathrm{Hg}$ than hairs of winter fur was, however, not supported by the finding that in only six samples, taken in July and August in eastern Greenland, the mean concentration was not significantly different from the mean concentration in hairs sampled in the same area during other seasons.

We suggest that the low $\mathrm{Hg}$ levels found in "summer" hair are caused by accelerated hair growth during the moult. However, it remains undetermined whether the different concentrations found at Svalbard (this study and Renzoni \& Norstrom 1990) also reflect sampling of different segments of the polar bear population at different times of the year and/or seasonal variations in the food of polar bears.

In samples from 55 polar bears taken between January and May in 1982 in seven areas within the central Canadian High Arctic, Renzoni \& Norstrom (1990) did not find a statistically significant correlation between total $\mathrm{Hg}$ in hair and live tissue. In contrast, in a smaller sample taken during spring in eastern Greenland we found that concentrations of total $\mathrm{Hg}$ in hair correlated positively with concentrations of total $\mathrm{Hg}$ in internal 
tissues with a capacity for long term accumulation of mercury. An explanation for this apparent discrepancy found in the two studies could be that samples from various areas in Canada were pooled in the Renzoni \& Norstrom (1990) study whereas the East Greenland material is more homogenenous since it was sampled in only one area.

The mercury concentrations in the hair as well as in the internal organs reflect the contamination levels in the food of the polar bears. Therefore, it appears less surprising that we found a correlation between $\mathrm{Hg}$ in hair and in internal tissues. This is in agreement with previous findings by for example Freeman \& Horne (1973), who stated that claws and fur from the Gray seal (Halichoerus grypus) and the harp seal (Pagophilus groenlandicus) were good indicators of the degree of mercury contamination in muscle, liver, kidney and heart tissue. Similarly, Bacher (1985) found a significant correlation between mercury in hair and in internal tissues (muscle, liver, spleen, brain) of Australian fur seals (Arctocephalus pusillus). Furthermore, if one regards hair as one of the excretion routes of $\mathrm{Hg}$ (see Itano et al. 1984), it seems reasonable to assume that $\mathrm{Hg}$ concentrations in hair in a general way reflect the $\mathrm{Hg}$ level in the internal tissues of an individual.

We conclude that concentrations of total mercury in polar bear hair from late winter and spring reflect the overall mercury burden in the ecosystem within the range of the various polar bear populations. We suggest that the relatively low concentrations of total mercury found in samples obtained during summer can be related to the process of moulting. Based on a small sample from eastern Greenland we have found indications that concentrations of total $\mathrm{Hg}$ in hair taken during spring reflect levels of total mercury in liver and kidney tissue.

Acknowledgements. - Wo wish to thank the Grcenland Inuit and our colleagues who provided the samples. Thanks are also due to the Canadian Wildlife Service (Edmonton) for making age determinations of some of the teeth, and to our laboratory technicians who made the metal analyses. We are grateful for the constructive criticism offered to the draft by $\mathrm{J}$. Hansen (Institute of Hygienc, University of Aarhus). R. Norstrom (Canadian Wildlife Service), and $\emptyset$. Wiig (Norwegian Polar Research Institute) and two anonymous referees.

\section{References}

Bacher, G. J. 1985: Mercury concentrations in the Australian fur seal (Arctocephalus pusillus) from SE Australian waters.
Bulletin of Environmental Contamination \& Toxicology 35, 490-495.

Born, E. W. \& Rosing-Asvid, A. 1989: Isbjørnen (Ursus maritimus) i Grønland: en oversigt (The polar bear in Greenland: a review). Teknisk rapport-Gronlands Hjemmestyre, Miljøog Naturforvaltning. 3900 Nuuk. Rapport Nr. 8-oktober $1989.126 \mathrm{pp}$. (in Danish with English summary).

Dietz, R. 1987: Tungmetaller i isbjørn og andre arktiske dyr/ Nannuni issittullu uumasuini allani saffugassat oqimaatsut (Heavy metals in polar bears and other Arctic animals). Forskning i Grønland / tusaat 1987 (2), 2-13 (in Danish and Greenlandic).

Dietz, R., Nielsen, C. O., Hansen. M. M. . \& Hansen, C. T. 1990: Organic mercury in Greenland birds and mammals. The Science of the Total Environment 95 (1990), 41-51.

Dietz, R. \& Agger, C. T. (in press): Recent studies on heavy metals in polar bears from Greenland with reference to other marine mammals. Abstract "Contaminants in the Arctic." 18th Annual Aquatic Toxicity Workshop, 30 September-3 October 1991, Ottawa, Canada.

Eaton, R. D. P. \& Farant J. P. 1982: The polar bear as a biological indicator of the environmental mercury burden. Arctic 35 (3), 422-425.

Freeman, H. C. \& Horne. D. A. 1973: Mercury in Canadian seals. Bulletin of Environmental Contamination \& Toxicology 10, 172-180.

Freuchen. P. 1935: Polar bears (Ursus maritimus). Pp. 102-119 in Mammals, Part II. Field notes and biological observations. Rep. Fifth Thule Expedition 1921-24, 2(4-5), 68-278.

Hansen, J. 1981: A survey of human exposure to mercury, cadmium and lead in Greenland. Meddr. Grønland Man. \& Society $3.36 \mathrm{pp}$.

Itano, K., Kawai, S., Miyazaki, N., Tatsukawa, R. \& Fujiyama, T. 1984: Mercury and selenium levels in striped dolphins caught off the Pacific coast of Japan. Agric. Biol. Chem. $48(5), 1109-1116$.

Jóhannesson, T., Lunde. G. \& Steinnes. E. 1981: Mercury, arsenic. cadmium, selenium and zine in human hair and salmon fries in Iceland. Acta pharmacol. et toxicol. 48, 185189.

Kershaw, T. G., Dhahir, P. J. \& Clarkson. T. W. 1980: The relationship between blood levels and dose of methyl mercury in man. Arch. Environ. Health 35, 28-35.

Larsen, T. 1986: Population biology of the polar bear (Ursus maritimus) in the Svalbard Area. Norsk Polarinstitutts Skrifter $184.55 \mathrm{pp}$.

Larsen. T.. Jonkel. C. \& Vibe, C. 1983: Satellite radio-tracking of polar bears between Svalbard and Greenland. Int. Conf. Bear Res. Manage. 5, 230-237.

Lønø, O. 1970: The polar bear (Ursus maritimus Phipps) in the Svalbard area. Norsk Polarinstitutts Skrifter 149.103 pp.

Norstrom, R. J., Schweinsburg, R. E. \& Collins, B. T. 1986: Heavy metals and essential elements in livers of the polar bear (Ursus maritimus) in the Canadian Arctic. The Science of the Total Environment 48, 195-212.

Pedersen, A. 1945: Der Eisbär (Thalarctos maritimus Phipps)Verbreitung und Lebensweise. Bruun \& Co., København. 16 pp. (in German).

Renzoni, A. 1989: Mercury in scalp hair of Maldivians. Marine Pollution Bulletin 20(2), 93-94.

Renzoni, A. \& Norstrom, R. 1990: Mercury in the hairs of polar bears Ursus maritimus. Polar Record 26(159). 326-328.

Renzoni, A., Focardi, S.. Fossi, C., Leonzio, C. \& Mayol, J. 1986: Comparison between concentrations of mercury and 
other contaminants in eggs and tissues of Cory's shearwater. Calonectris diomedea collected on Atlantic and Mediterranean islands. Environmental Pollution. Ser. A 40. 1735.

Rosing-Asvid. A. \& Born, E. W. 1990: Fangst af isbjorn (Ursus maritimus) i Avanersuaq og Upernavik kommuner: en interviewundersøgelse (Polar bear hunting in the Avanersuaq and Upernavik areas: an interview survey). Teknisk rapport Gronlands Hemmestyre Afdelingen for Levende Ressourcer. 3900 Nuuk. Nr. 23 -december 1990.63 pp. (in Danish with English summary).

Rutilerski. G. L. 1939: Promyslovye mlekopitajuscic poluostrowa Celjuskina i zaliva Vilkickogo. Trudy naucn.issled, poliarn. $\times$. 7-601. (in Russian. not consulted dircilyl.

Sexton. D. J., Powell, K. E.. Liddle. J. \& Sinrek. A. 1978: A nonoccupational outbreak of inorganic mercury poisoning. Arch. Environ. Health 3. 186-191.

Smith. T. G. \& Armstrong. F. A. J. 1975: Mercury in scals, terrestrial carnivores. and principal food items of the Inuit from Holman. NWT. J. Fish. Res. Bd. Can. 32 (6), 795-801. Stirling. I. \& Archibald, R. 1977: Aspects of predation of seals by polar bears. J. Fish. Res. Bd. Can. 34(8), 1126-1129.

Stirling. I., Archibald, W. R. \& Schwcinsburg, R. E. 1977: Distribution and abundance of scals in the eastern Bcaufort Sea. J. Fish. Res. Bd. Can. 24, 976-988.

Uspenski, S. M. 1979: Der Eisbär. Die Neue Brehm-Bücherei. A Ziemsen Verlag. Wittenberg Lutherstadt. 112 pp. (in German).

Vibe C. 1981: Isbjorn (Ursus maritimus), Nanok (Polar bear). Pp. 383-387 in Salomonsen, F. (ed.): Gronlands Fauna. Fisk, Fugle, Pattedyr. Gyldendal, København. 464 pp. (in Danish). 